\title{
АНАЛІЗ НАУКОВИХ ДОСЛІДЖЕНЬ ЩОДО ПРОЕКТУВАННЯ ТРАНСПОРТНИХ МЕРЕЖ ВИСОКОШВИДКІСНОГО ТА ЗВИЧАЙНОГО РУХУ
}

Канд. техн. наук А.В. Прохорченко, магістр Д.О. Кравченко

\section{АНАЛИЗ НАУЧНЫХ ИССЛЕДОВАНИЙ ПО ПРОЕКТИРОВАНИЮ ТРАНСПОРТНЫХ СЕТЕЙ ВЫСОКОСКОРОСТНОГО И ОБЫЧНОГО ДВИЖЕНИЯ}

Канд. техн. наук А.В. Прохорченко, магистр Д.А. Кравченко

\section{ANALYSIS RESEARCH ON TRANSPORT NETWORKS DESIGN OF HIGH-SPEED AND CONVENTIONAL MOVEMENT}

\author{
Cand. of tehn sciences A. Prokhorchenko, master student D. Kravchenko
}

Робота присвячена аналізу наукових досліджень щодо пошуку раціональної топології транспортних мереж в умовах реалізації високошвидкісного та звичайного руху поїздів. Досліджено еволючію підходів до принципів побудови математичної моделі для проектування транспортних мереж. Сформульовано принципи для побудови математичної моделі, яка дасть змогу визначити топологію залізничної мережі, щя відповідає реальним умовам функиіонування залізниць Украӥни.

Ключові слова: транспортна система, топологія, залізнична мережа, поӥздопотік, високошвидкісні магістралі.

Работа посвящена анализу научных исследований по поиску рациональной топологии транспортных сетей в условиях реализачии высокоскоростного и обычного движения поездов. Исследована эволючия подходов относительно принципов построения математической модели для проектирования транспортных сетей. Сформулированы принципы для построения математической модели, которая позволит определить топологию железнодорожной сети, соответствующей реальным условиям функционирования железных дорог Украины.

Ключевые слова: транспортная система, топология, железнодорожная сеть, поездопоток, высокоскоростные магистрали.

Work devoted to the research for finding rational topology transport networks in terms of implementing high-speed and conventional trains. The evolution of approaches to principles of mathematical models for the design of transport networks. Detailed research in the design of transport networks based on the analysis of spatio-topological and geometrical properties of networks. Analyzed studies that examine forming topology as the interaction between network users with simple rules based on individual agentbased approach. The results of recent studies based on statistical analysis of the macro properties of complex networks. Proved that the macro characteristics of complex transport system is not formed on the basis of central planning from the top down, as defined by the rising of the interaction of the components of the simple rules leads to hierarchy, which is a consequence of the existence of self-organization in the system. The principles for building a mathematical model that will determine the topology of the railway network that meets the real terms of railways of Ukraine.

Keywords: transport system, topology, railway network, trains flow, high-speed rail.

Вступ. В умовах підвищення вимог до якості здійснення вантажних перевезень та впровадження швидкісного руху пасажирських поїздів для залізниць України $\epsilon$ важливим знайти раціональну топологію залізничної мережі для задоволення потреб ринку транспортних послуг. Для вирішення поставленої наукової проблеми необхідним $\epsilon$ теоретичне обгрунтування підходів до принципів побудови математичної моделі для пошуку раціональної мережі залізниць.

Визначення мети та задачі дослідження. Дана робота має на меті аналіз сучасного стану досліджень у галузі проблем 
проектування мереж (англ. Network Design Problems), критичний огляд існуючих підходів, узагальнення результатів та формулювання принципів для побудови математичної моделі, яка дасть змогу визначити топологію мережі, що відповідає реальним умовам функціонування залізниць України.

Основна частина дослідження. Перші теоретичні дослідження проблем проектування мереж почалися 3 появою наукових робіт Леонарда Ейлера у 1736 року в галузі топології та стрімкого розвитку теорії графів. Уже у 1891 році Е. Лілль [1], застосувавши статистичний підхід, дослідив залежність кількості поїздок від дальності та сформулював так званий закон подорожей (закон Лілля), що став основоположним для потенціальної теорії пасажирських потоків [2]. Майже до кінця 1950-х років весь напрямок досліджень був спрямований на закономірності, що виникають на окремих сполученнях у транспортній мережі.

Уперше у 1924 році Френк Найт, а в подальшому інші вчені звернули увагу на виникаючу рівновагу при розподілі транспортних потоків у мережі [3, 4]. Це дало змогу у 1952 році Джону Уордропу сформулювати так звані поведінкові принципи користувачів транспортної мережі [5]. Дані принципи отримали назву перший та другий принцип Вардропа [4]. Згідно 3 принципами Вардропа в транспортній мережі користувачі взаємодіють між собою спираючись на повний егоїзм - кожен прагне вибрати маршрут руху в мережі з позиції особистих критеріїв вибору, а конкурентна взаємодія між користувачами призводить до рівноважного стану в мережі. У другому принципі Вардроп стверджував, що при централізованому управлінні рухом також досягається системна рівновага в мережі.

З 1960 року, після так званої "кількісної революції", у роботах представників школи просторового аналізу з'явилися комплексні дослідження розвитку транспортних мереж. У 1963 році Е. Тааффе, Р. Моррілл та П. Гульд запропонували чотириетапну модель процесу розвитку топології дорожньої мережі в нерозвиненому місті [6]. В. Гарісон та Д. Марбл провели дослідження щодо моделювання еволюції топології залізничної мережі Північної Ірландії між 1830 і 1930 роками із використанням методу Монте-Карло [7]. Паралельні дослідження провів Р. Моррілл у
1965 році для залізничних мереж центральної Швеції [8]. У 1969 році К. Канський запропонував кількісну прогнозну модель розвитку структури мережі, яку застосував до моделювання розвитку сицилійської залізниці [9]. Ці дослідження грунтувалися на спробах описати топологічні перетворення в мережі на основі інтуїтивних механізмів, що копіюють зміни у геометрії мережі. Такий підхід не враховував демографічні та поведінкові механізми, що впливають на еволюцію мережі. Причому дослідження суттєво обмежувались існуючими на той час обсягами даних, обчислювальними потужностями і відомими методами моделювання.

3 1970-х років виникли наукові роботи $[10,11]$, у яких почали досліджувати, як прогнозний попит та поведінкові принципи користувачів впливають на розвиток топології транспортних мереж. Набувають поширення математичні моделі прогнозування попиту на поїздки [4]. 3'явилася можливість прогнозувати транспортні потоки, що дало змогу наблизитись до реалістичного розподілу транспортних потоків у мережах та знаходити оптимальні структури транспортних мереж, які максимізують ефективність поїздок. Спираючись на дослідження щодо пошуку рівноважних потоків у мережі у 1968 році С. Дафермос та Ф. Сперроу вперше для пошуку розподілу потоку в мережі застосували алгоритм Франк-Вольфа [12]. У результаті досліджень з 1966 року А. Вільсон для розрахунку кореспонденцій пасажирів у місті запропонував застосувати підхід на основі концепції ентропії транспортної системи [13]. В основі даного підходу запропонована гіпотеза про те, що стан рівноваги в макросистемі досягається при максимумі іiї ентропії, але при цьому повинні виконуватись деякі додаткові умови, що враховують обмеженість ресурсу, який міститься в системі. Вищезазначені дослідження зводяться до оптимізаційних задач пошуку оптимальних структур транспортних мереж, тобто в задачах існує цільова функція ефективності всієї системи, що призводить до знаходження топології мережі 3 позиції централізованого управління. Такий підхід не дає змоги врахувати складну взаємодію постачальників i користувачів на мікрорівні системи. Слід зазначити, дослідження на основі оптимізації не втратили своєї актуальності, так як аналіз емпіричних даних розвитку багатьох 
транспортних мереж показав, що у короткостроковій перспективі планування відіграє важливу роль, і транспортна система еволюціонує за допомогою процесу оптимізації. Тоді як у довгостроковій перспективі більшість систем у результаті додавання послідовних шарів, i навіть якщо кожен 3 цих шарів $є$ результатом процесу оптимізації, то загальна топологія мережі довгий час є неоптимальною [14].

На початку 1990 років з'являються дослідження, які розглядають формування топології мережі як процес взаємодії користувачів мережі 3 простими індивідуальними правилами. У 1993 році Л. Лем та Р. Почі запропонували так звану активно-пішохідну модель (англ. active-walker model, AWM) на основі агентно-орієнтованого підходу [15]. Д. Хелбінг, Й. Келтч та П. Молнар у 1997 році також запропонували агентну модель пішохідної динаміки [16]. Агентноорієнтовані моделі імітаційного моделювання дали змогу формалізувати процес еволюції транспортної мережі на основі принципів колективної самоорганізації. Даний підхід дає можливість підвищити реалістичність моделювання процесів, що відбуваються при еволюції топології мережі, але не дає змоги знаходити оптимальні рішення. Даний напрямок досліджень не втратив актуальності та інтенсивно розвивається [17].

Останніми роками дослідження в галузі проектування транспортних мереж змістили акцент 3 аналізу просторово-топологічних i геометричних властивостей до статистичних макровластивостей складних мереж, зокрема транспортних. У 1998 році Д. Уоттс та С. Строгатц статистично довели, що в реальних просторових мережах існує ефект малого світу (англ. small world effect) [18]. Дослідження топологічної динаміки мереж 3 позиції статистичної фізики довели існування властивості масштабної інваріантності в складних мережах. Так, у 1999 році Л. Барабаші та Р. Альберт вперше довели, що емпіричний розподіл степеня вершин підпорядковується степеневому закону, а отже, даний експериментальний результат спростовує розподіл зв'язків у мережі за законом Пуассона [19]. Це підтверджує, що граф мережі не $\epsilon$ випадковим, а його розвиток лежить в основі процесів самоорганізації складних нелінійних систем. Мережі, що мають такі властивості, отримали назву так званих безмасштабних мереж (англ. free-scale networks).

Отже, останні дослідження в галузі проблем проектування мереж підтверджують, що макрохарактеристики складної транспортної системи не формуються на основі централізованого планування зверху вниз, а визначаються шляхом висхідного процесу взаємодії компонентів системи за простими правилами, що призводить до виникнення iєрархії, яка $€$ наслідком існування самоорганізації в системі [20, 21]. Запропонований А. Барабаші принцип переважного приєднання (англ. preferential attachment), по суті, є джерелом виникнення ієрархії в мережі. Складна мережа розвивається в результаті взаємодії 3 навколишнім середовищем, спираючись на "успішних" агентів системи, посилюючи їх, у той час як менш успішні агенти стають застарілими або навіть відмирають (дегенерують). У 2005 році Бхану Йєрра та Д. Левінсон довели, що транспортні мережі з фіксованою структурою можуть диференціюватися у вигляді ієрархічної структури 3 будь-яким випадковим або однорідним станом [22]. Причому аналіз показав, що не 3 причин оптимізації структури мережі, а при утворенні ієрархії залізниць виникають властивості мережі та динаміка транспортного потоку.

Аналіз досліджень щодо проектування мереж саме для залізничного транспорту показав існування великої кількості робіт, що присвячені пошуку топологій комплексних залізничних систем 3 централізованим управлінням. Так, у роботі Р.К. Ахаджа та ін. [23] запропоновано комплексний підхід до проектування залізничної мережі для вантажних перевезень у США. Д. Мідделкуп та М. Бауман запропонували комплексну систему планування для Голландської залізничної мережі [24]. Дослідженням щодо пошуку раціональної топології мережі високошвидкісних пасажирських перевезень на залізницях присвячені роботи $[25,26]$. Набагато менше наукових робіт щодо проектування залізничних мереж, у яких розділені функції інфраструктури та експлуатації. Окремі питання для проектування такого класу мереж розглянуті в роботах $[27,28]$.

Висновок. Проведений аналіз показав ряд недоліків існуючих підходів до пошуку раціональної топології транспортної мережі: 
відомі дослідження, що базуються на оптимізаційному підході формують структуру мережі за принципом “зверху вниз”, тим самим нехтуючи процесом самоорганізації, який лежить в основі еволюції топології мережі; багато досліджень присвячено пошуку топологій комплексних транспортних систем 3 централізованим управлінням, тоді як майже не існує підходів до проектування залізничних мереж, у яких розділені функції інфраструктури та експлуатації. Існує єдина компанія, що управляе залізничною інфраструктурою, яка має глобальний критерій ефективності функціонування мережі та багато компаній-перевізників, які конкурують між собою і мають різні критерії ефективності свого функціонування; відомі дослідження не враховують статистичний аналіз макровластивостей реальних залізничних мереж, що дало б змогу підвищити точність пошуку раціональної топології мережі, що відповідає реальним умовам функціонування. Урахування вищезазначених недоліків при побудові математичної моделі проектування залізничної мережі для високошвидкісного та звичайного руху поїздів дасть змогу підвищити ефективність пошуку топології залізничної мережі, що відповідає реальним умовам функціонування залізниць України.

\section{Список використаних джерел}

1. Lill, E. Das Reisegesetz und seine Anwendung auf den Eisenbahnverkehr (The Trip Law and its Use for Railway Traffic) [Text]. Spielhagen \& Schurich. German, Wien. $-1891 .-41$ p.

2. Поттгофф, Г. Учение о транспортных потоках [Текст] / перевод с нем. Шейко В.И. и Воскресенского В.Н.; под ред. Е.П. Нестерова. - М.: Транспорт, 1975. - 344 с.

3. Knight, F.H. Some fallacies in the interpretation of social cost [Text] / F.H. Knight // The Quarterly Journal of Economics. - 1924. - V. 38(4). - P. 582-606.

4. Введение в математическое моделирование транспортных потоков[Текст]: учеб. пособие / А.В. Гасников, С.Л. Кленов, Е.А. Нурминский [и др.]; Приложения: М.Л. Бланк, Е.В. Гасникова, А.А. Замятин [и др.]; под ред. А.В. Гасникова. — М.: МФТИ, 2010. - 362 с.

5. Wardrop, J. C. Some Theoretical Aspects of Road Traffic Research [Text] / J.C. Wardrop // Proceedings, Institution of Civil Engineers Part 2. - 1952. - 9. - P. 325-378.

6. Taaffe, E. Transportation expansion in underdeveloped countries: A comparative analysis [Text] /

E. Taaffe, R. L. Morrill, P. R. Gould // Geographical Review. - 1963- 53(4). - P. 503-529.

7. Garrison, W.L. The structure of transportation networks [Text] / W. L. Garrison, D.F. Marble // U.S. Army Transportation Command, Technical Report 62-II. - 1962.

8. Morrill, R. L. Migration and the growth of urban settlement [Text] / Richard L. Morrill // Lund Studies in Geography Series B Human Geography. - 1965. - 26. - P. 65-82.

9. Kansky, K. Structure of transportation networks: Relationships between network geometry and regional characteristics [Text] / K.J. Kansky // Chicago: University of Chicago. - 1969. - Research Paper No. 84.

10. LeBlanc, L.J. An algorithm for the discrete network design problem [Text] / L. J. LeBlanc // Transportation Science. - 1975. - 9(3) . - P.183-199.

11. Newell, G.F. Traffic Flow on Transportation Networks [Text]. Cambridge, Massachusetts: The MIT Press Series in Transportation Studies. $-1980 .-276$ p.

12. Dafermos, S.C. The Traffic Assignment Problem for a General Network [Text] / Stella. C. Dafermos, F.T. Sparrow // J. of Res. of the National Bureau of Standards. - 1969. - 73B. - P. 91-118.

13. Вильсон, А.Дж. Энтропийные методы моделирования сложных систем [Текст]: пер. с англ. / А.Дж. Вильсон. - М.: Наука, 1978. - 248 с. $-101 \mathrm{p}$.

14. Barthélemy, M. Spatial networks [Text] / M. Barthélemy // Physics Reports. - 2010. - Vol.499(1).

15. Lam, L. Active-walker models: Growth and form in nonequilibrium systems [Text] / L. Lam, R. Pochy // Computation Simulation. - 1993. - Vol.7. - 534-541.

16. Helbing, D. Modeling the evolution of human trail systems [Text] / D. Helbing, J. Keltsch, P. Molnár // Nature. - 1997. - Vol.388. - P. 47-50. 
17. Yamins, D. Growing urban roads [Text] / D. Yamins, S. Rasmussen, D.Fogel //. Networks and Spatial Economics. - 2003. - Vol.3. - P. 69-85.

18. Watts, D.J. Collective dynamics of 'small-world' networks [Text] / D.J. Watts, S.H. Strogatz //Nature. - 1998. - 393. - P. 440-442.

19. Barabási, A.L. Emergence of scaling in random networks [Text] / A. L. Barabasi, R. Albert // Science. - 1999. - Vol.286. - P. 509-512.

20. Albert, R. Statistical mechanics of complex networks [Text] / Reka Albert, Albert-Laszlo Barabási // Reviews Of Modern Physics. - 2002. - Vol. 74. - P. 47-97.

21. Newman, M.E.J. The structure and function of complex networks [Text] / M.E.J. Newman // SIAM REVIEW. - 2003. - 45. - P. 167-256.

22. Yerra, B. The emergence of hierarchy in transportation networks [Text] / B. Yerra, D. Levinson // Annals of Regional Science. - 2005. - Vol.39(3) . - P. 541-553.

23. Ahuja, R.K. Solving real-life railroad blocking problems [Text] / R.K. Ahuja, K.C. Jha, J. Liu // Interfaces. $-2007 .-37 .-$ P. 404-419.

24. Middelkoop, D. Train network simulator for support of network wide planning of infrastructure and timetables [Text] / D. Middelkoop, M. Bouwman // In Computers in Railways. - 2000. - VII. - P. 267276.

25. Wang, L. A two-layer optimization model for high-speed railway line planning [Text]/ Li Wang, Li-min Jia, Yong Qin, Jie Xu, Wen-ting Mo// Journal of Zhejiang University-SCIENCE A (Applied Physics \& Engineering). - 2011. - Vol. 12. - Is. 12. - P. 902-912.

26. Бараш, Ю.С. Аналіз наукових підходів щодо обгрунтування економічної доцільності будівництва в Україні високошвидкісних магістралей [Текст] / Ю.С. Бараш, А.В. Момот // Проблеми транспортного комплексу України. Вісник економіки транспорту і промисловості. - 2012. - № 40 C. 83-86.

27. Niekerk, F. Impact assessment for infrastructure planning: some dutch dilemmas [Text] / F. Niekerk, H. Voogd // Environmental Impact Assessment Review. - 1999. - 19. - P.21-36.

28. Borndörfer, R. Railway Track Allocation - Simulation, Aggregation, and Optimization [Text] / Ralf Borndörfer, Thomas Schlechte, Elmar Swarat // Proceedings of the 1st International Workshop on HighSpeed and Intercity Railways Lecture Notes in Electrical Engineering. - 2012. - Vol. 148. - P. 53-69.

Рецензент д-р техн. наук, професор О.М. Огар

Прохорченко Андрій Володимирович, канд. техн. наук, доцент, кафедра управління експлуатаційною роботою, Український державний університет залізничного транспорту. Тел.: (057) 730-10-88. E-mail: railwayhub@yandex.ua.

Кравченко Дмитро Олександрович, студент гр. МЗ-ОПУТ-14, магістр, Український державний університет залізничного транспорту. Тел.: (057) 730-10-88. E-mail: uer_mp@ukr.net.

Prokhorchenko Andrii Ph.D., Associate Professor, Department of Management of operational work, Ukrainian State University of Railway Transport. Tel.: (057) 730-10-88. E-mail: railwayhub@yandex.ua.

Kravchenko Dmitrii, st. gr. MZ-OPUT-14, Ukrainian State University of Railway Transport. Tel.: (057) 730-10-88. Email: uer_mp@ukr.net.

Наукова праця здана до друку 26.06.2015 року 